\title{
Influence of synthesis conditions on physical properties of lanthanide-doped titania for photocatalytic decomposition of metazachlor
}

\author{
Marcela Kralova a,*, Irina Levchuk ${ }^{b}$, Vit Kasparek ${ }^{a}$, Mika Sillanpaa ${ }^{b}, J_{\text {Jaroslav Cihlar }}{ }^{a}$ \\ a Central European Institute of Technology, Brno University of Technology, Brno, Czech Republic \\ ${ }^{\mathrm{b}}$ Laboratory of Green Chemistry, Lappeenranta University of Technology, Mikkeli, Finland
}

A R T I C L E I N F O

Article history:

Received 28 February 2015

Accepted 17 June 2015

Published 20 October 2015

\section{Keywords:}

Lanthanide-doped titania

Dysprosium

Praseodymium

Synthesis condition

Photocatalytic decomposition

Metazachlor

\begin{abstract}
A B S T R A C T
Heterogeneous photocatalysis is a very effective method for the decomposition of a whole range of water pollutants. In this work, the influence of synthesis conditions on the physical properties and photocatalytic activity of lanthanide-doped titanium dioxide photocatalysts was evaluated. Titanium dioxide was prepared via sol-gel synthesis followed by a solid state reaction under different conditions, including different temperatures $\left(450,550\right.$, and $\left.650{ }^{\circ} \mathrm{C}\right)$ and reaction times $(4,8$, and 12 h). The crystalline phase of the products was determined to be solely anatase using X-ray diffraction, and this result was confirmed by Raman spectroscopy. The structure, as well as particle size, of the samples was examined using scanning electron microscopy, and their specific surface area was calculated using Brunauer-Emmett-Teller analysis. The band gap energy of the samples was examined using ultraviolet-visible spectroscopy from diffuse reflectance measurements. Doping with lanthanide species, dysprosium and praseodymium, caused the absorption edge to shift towards higher wavelengths and enhanced photocatalytic activity in comparison with pure titania. The photocatalytic activity of the samples was studied in terms of the degradation of the commonly used herbicide metazachlor. The decomposition was carried under UV light and the decrease in metazachlor concentration was measured using high performance liquid chromatography. The best performance was obtained for samples treated at $550^{\circ} \mathrm{C}$ for $8 \mathrm{~h}$ during the solid state reaction step.
\end{abstract}

(C) 2015, Dalian Institute of Chemical Physics, Chinese Academy of Sciences. Published by Elsevier B.V. All rights reserved.

\section{Introduction}

Metazachlor belongs to the organochlorine pesticide group and was the fifth most used herbicide in the Czech Republic in 2010, with a consumption of nearly $200000 \mathrm{~kg}$ [1]. Generally, residues of various pesticides and herbicides are able to leach from agricultural soil to deeper ground or to ground water, where they can remain for long time owing to their nondegradable properties. Consequently, such species can cause different serious problems even at very low doses of nanograms per cubic decimeter [2]. Metazachlor has been found to be moderately toxic to different aqueous organisms, especially daphnia, carp, and bluegill sunfish. The highest sensitivity was discovered in trout, where it can cause damage to liver or kidneys [3]. Because of its toxicity, metazachlor, as with many other pesticides, belongs to large group of endocrine disrupting chemicals (EDCs) [4]. Many of these compounds pass through wastewater treatment plants $[5,6]$ that are not designed for removing such contaminants [7], and therefore many of them reach the surface water unchanged [8].

Many different techniques have been studied in the effort to remove micropollutants from water, from physical processes,

* Corresponding author. Tel: +420 541143 340; Fax: +420 541211 309; E-mail: marcela.kralova@ceitec.vutbr.cz 
such as sorption or membrane filtration, to biological processes, using bacteria or enzymes [9]. Nowadays, one very promising group of treatment techniques is that based on advanced oxidation processes, particularly heterogeneous photocatalysis. The main feature of this method is the production of hydroxyl radicals, which initiate subsequent reactions that lead to the decomposition and removal of organic compounds [10]. This technology is also non-selective and versatile, which are useful and necessary in wastewater treatment [11]. Titanium dioxide is one of the most commonly used photocatalysts because of its high activity, biological and chemical inertness, high photostability, excellent optical and electrical properties, and nontoxicity. However, its absorption only in the UV region and quite narrow band gap energy, which brings about fast back recombination of the electron-hole pair, are its main disadvantages. Many authors have attempted either to shift the absorption edge of titania towards higher wavelength, or to suppress the recombination process, which may be achieved by doping the titania [12]. Nevertheless, most studies concentrate their photocatalytic investigations on model compounds $[13,14]$ such as phenol or dyes $[15,16]$.

In this work we successfully prepared lanthanide-doped titanium dioxide, which has been reported to exhibit better photocatalytic activity in comparison with that of pure titania [17], and investigated its suitability for the photocatalytic decomposition of metazachlor because of the current need to remove this species from wastewater. Furthermore, we investigated the effects of different process conditions and compared the photocatalytic activity of doped and undoped samples with commercial titania P25.

\section{Experimental}

\subsection{Catalyst preparation}

Preparation of lanthanide-doped titanium dioxide was performed by sol-gel synthesis using titanium propoxide as the precursor. The titanium propoxide $(0.125 \mathrm{~mol})$ was added dropwise under continuous stirring to isopropanol $(0.5 \mathrm{~mol})$, which was used as a solvent. Afterwards, acetylacetone ( $0.06 \mathrm{~mol})$ was added to the mixture as a stabilization agent. Dysprosium (Dy) and praseodymium (Pr) doped $\mathrm{TiO}_{2}$ (0.3 mol\% [18]) samples were synthesized by first dissolving the oxides of the corresponding elements in nitric acid $\left(20 \mathrm{~cm}^{3}\right)$, and the obtained solutions were poured into the propoxide dispersions. The sols were left to age at room temperature for $7 \mathrm{~d}$ to form a gel structure, after which they were heated at $120^{\circ} \mathrm{C}$ until xerogels were formed. The xerogels were then subjected to solid state reaction at various temperatures $\left(T=450,550\right.$, and $\left.650^{\circ} \mathrm{C}\right)$ for different time periods $(t=4,8$, and $12 \mathrm{~h}$ ). The obtained lanthanide-doped $\mathrm{TiO}_{2}$ samples were denoted as $\mathrm{Dy}-\mathrm{TiO}_{2} \mathrm{~T} / t$ and $\mathrm{Pr}-\mathrm{TiO}_{2} \mathrm{~T} / t$.

\subsection{Catalyst characterization}

Thermogravimetric analysis (TGA) was carried out on the heat-treated powders using a thermoanalyzer (Seiko Instru- ments 6300 TG-DTA) in an atmosphere of argon-air (volume ratio $1: 1)$. The analysis was performed over the temperature range $35-1000{ }^{\circ} \mathrm{C}$, with a gas flow rate of $400 \mathrm{~cm}^{3} / \mathrm{min}$ and a temperature ramp rate of $20^{\circ} \mathrm{C} / \mathrm{min}$. The crystalline phase of the prepared powders was examined using X-ray diffraction (XRD; X-ray diffractometer SmartLab, Rigaku), using a $\mathrm{Cu} K_{\beta}$ radiation source and a $2 \theta$ scan range of $20^{\circ}-60^{\circ}$. The results of the XRD measurements were confirmed by Raman analysis (Renishaw inVia), which was carried out using a $633 \mathrm{~nm}$ laser at an output power of $30 \mathrm{~mW}$ and measured range of $0-1600 \mathrm{~cm}^{-1}$. Crystallite size was calculated from the XRD results using the Scherrer equation $d=B \lambda /(\beta \cos \theta)$, where $d$ is the size of the crystallites in the direction vertical to the corresponding lattice plane, $B$ is a constant equal to $0.94, \lambda$ is the wavelength, equal to $0.157 \mathrm{~nm}$, and $\beta$ is the width of the selected peak at half of its height.

The structure of the prepared powders, as well as their particle size, was investigated using scanning electron microscopy (SEM; Carl Zeiss Ultra Plus). The influence of synthesis conditions on the band gap energy was examined from diffuse reflectance measurements (UV-Vis spectrometer Avaspec-2048). Nitrogen adsorption/desorption analysis was carried out to determine the specific surface area of the samples (BET).

\subsection{Photocatalytic experiments}

The aim of this study was to determine optimal solid state reaction for the preparation of photocatalytically active nanopowders that could be useful for decomposition of pesticides in water. The photocatalytic experiments were performed on metazachlor. All experiments were carried out in a flow reactor (Fig. 1), which was composed of a borosilicate glass tube with inner diameter of $0.6 \mathrm{~cm}$ placed at a distance of $1 \mathrm{~cm}$ from the light source. The decomposition reaction was performed using UV-LED (370 $\mathrm{nm}$ ) irradiation with an optical power density of $22 \mathrm{~mW} / \mathrm{cm}^{2}$. The flow rate in the reactor was $2.5 \mathrm{~cm}^{3} / \mathrm{s}$. Before each experiment, the $\mathrm{Dy}-\mathrm{TiO}_{2}$ or $\mathrm{Pr}_{-\mathrm{TiO}}$ sample $(1 \mathrm{~g} / \mathrm{L})$ was dispersed in $70 \mathrm{~cm}^{3}$ of an aqueous solution of metazachlor (10 $\mathrm{mg} / \mathrm{L}$ ), and the resulting suspension was kept in darkness for $6 \mathrm{~min}$ under continuous stirring to reach adsorption/desorption equilibrium. $1 \mathrm{~cm}^{3}$-aliquots of the reaction solution were sampled at certain intervals, and the concentration of remaining metazachlor was determined by HPLC (Shimadzu LC-20) after filtration (pore size $0.45 \mu \mathrm{m}$ ). The HPLC conditions were as follows: Luna 5u C18 (2) 100A (250 mm $\times$ $4.6 \mathrm{~mm}$ ) column, the eluent was a mixture of water-acetonitrile (volume ratio $1: 1$ ) with a flow rate of $1.8 \mathrm{~cm}^{3} / \mathrm{min}$, column temperature $40^{\circ} \mathrm{C}$, injection volume $0.25 \mu \mathrm{L}$, and detector wavelength $210 \mathrm{~nm}$.

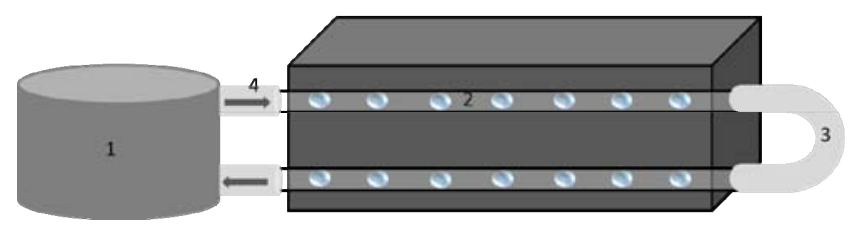

Fig. 1. Flow tube reactor. 1 , beaker containing reaction mixture; 2 , UV-LED source; 3 , borosilicate tube; 4 , direction of flow. 


\section{Results and discussion}

\subsection{Thermogravimetric analysis}

TGA experiments on the heat treated powders revealed a mass loss no higher than $3 \%$ for all samples. An example TGA/DSC trace is given in Fig. 2. The mass loss in the first temperature interval $\left(35-175^{\circ} \mathrm{C}\right)$ was caused by desorption of water physically adsorbed by the sample from humid air. The mass loss in the second temperature range $\left(175-500^{\circ} \mathrm{C}\right)$ may be a result of oxidation of organic residues, mainly acetylacetone, remaining in the powder owing to slow oxygen diffusion through titania layers during the solid state reaction. A lesser loss of mass was observed in the third temperature interval $\left(500-700^{\circ} \mathrm{C}\right)$, attributed to removal of the last organic residues that had formed a donor-acceptor bond between $\mathrm{Ti}$ atoms and the carbonyl group of acetylacetone. The exothermic peak around $650^{\circ} \mathrm{C}$ is ascribed to the phase transformation of anatase to rutile.

\subsection{Phase composition of nanopowders}

The influence of process conditions on the crystalline phase of the obtained samples was evaluated by XRD analysis, as shown in Fig. 3. All the prepared samples were found to be pure anatase, which implies that the Pr and Dy doping suppressed the creation of the rutile phase, which is expected to occur at $650{ }^{\circ} \mathrm{C}$. This result is in good agreement with the literature $[19,20]$. The crystallite size of the samples was calculated using the Scherrer equation and was found to increase with the temperature of the solid state reaction. In contrast, no influence of synthesis time on crystallite size was observed. Subsequently, the phase composition was studied by Raman analysis,

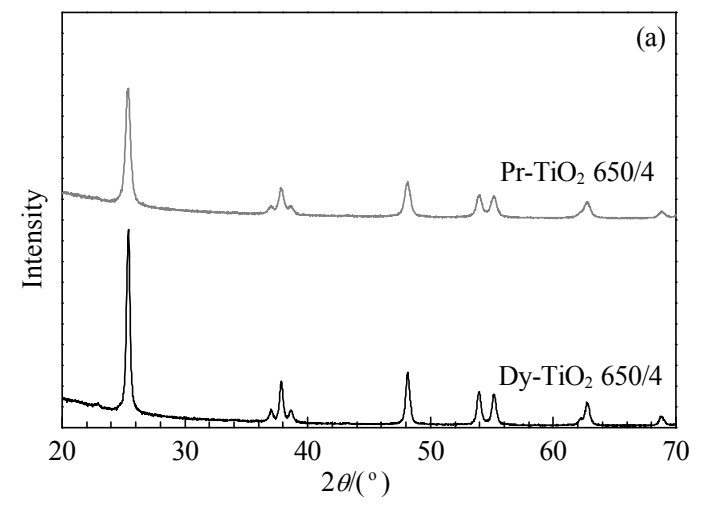

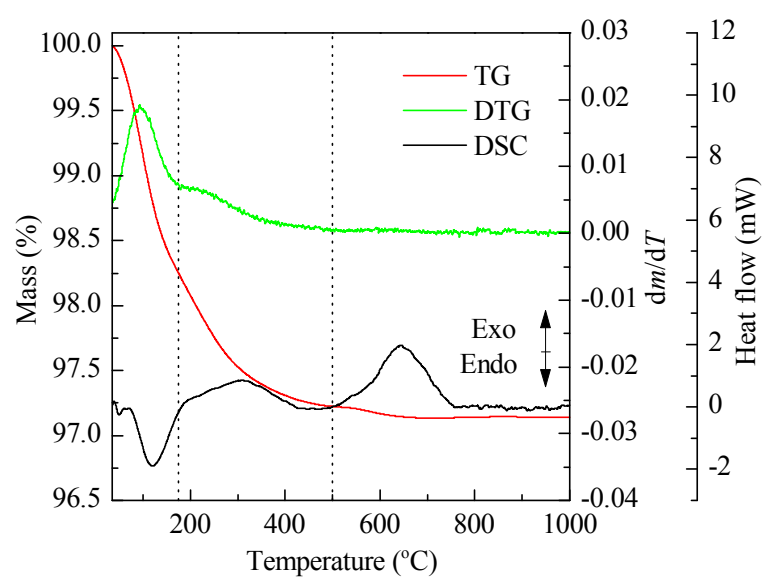

Fig. 2. Recorded data from the thermogravimetric analysis of sample Pr-TiO 2 450/4.

which confirmed the results from XRD. All of the obtained results are summarized in Table 1.

\subsection{Band gap energy evaluation}

The optical properties, especially the band gap energy, of the samples were investigated using UV-Vis spectroscopy by diffuse reflectance measurements. The band gap energy was calculated according to the Kubelka-Munk theory [21] using function $f\left(R_{\infty}\right)=\left(1-R_{\infty}\right)^{2} / 2 R_{\infty}$, where $R_{\infty}=R_{\text {sam }} / R_{\text {st. }}$. The diffusion reflectance of barium sulfate was used as a standard $\left(R_{\mathrm{st}}\right)$; $R_{\text {sam }}$ is the diffused reflectance of the samples. The relationship between the band gap energy $E_{\mathrm{g}}$ and the absorption coefficient, which can be obtained from the reflectance measurements, is: $\alpha h v=C\left(h v-E_{\mathrm{g}}\right)^{2}$, where $C$ is a proportionality constant. If the material scatters perfectly, the equation becomes: $\left[f\left(R_{\infty}\right) h v\right]^{1 / 2}$

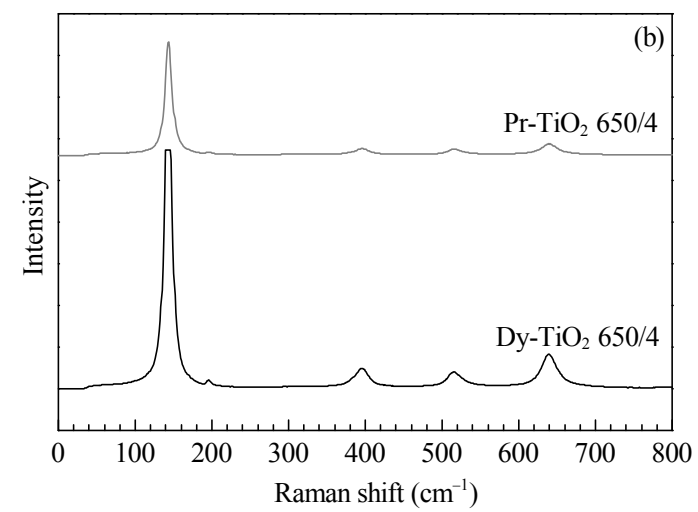

Fig. 3. XRD patterns (a) and Raman spectra (b) for $\mathrm{Pr}^{-} \mathrm{TiO}_{2}$ 650/4 and $\mathrm{Dy}-\mathrm{TiO}_{2}$ 650/4 samples, indicating the formation of pure anatase.

Table 1

Crystalline phase and crystallite size of the samples.

\begin{tabular}{|c|c|c|c|c|c|c|c|c|}
\hline \multirow{2}{*}{$\begin{array}{l}\text { Treatment } \\
\text { conditions } \\
\left({ }^{\circ} \mathrm{C} / \mathrm{h}\right) \\
\end{array}$} & \multicolumn{4}{|c|}{ Dy- $\mathrm{TiO}_{2}$} & \multicolumn{4}{|c|}{ Pr-TiO 2} \\
\hline & $\begin{array}{c}\text { Crystalline phase } \\
\text { (XRD/Raman) }\end{array}$ & $\begin{array}{c}\text { Crystallite size } \\
\text { (nm) }\end{array}$ & $\begin{array}{c}E_{\mathrm{g}} \\
(\mathrm{eV})\end{array}$ & $\begin{array}{l}\text { Absorption edge } \\
(\mathrm{nm})\end{array}$ & $\begin{array}{c}\text { Crystalline phase } \\
\text { (XRD/Raman) }\end{array}$ & $\begin{array}{c}\text { Crystallite size } \\
\text { (nm) }\end{array}$ & $\begin{array}{c}E_{\mathrm{g}} \\
(\mathrm{eV})\end{array}$ & $\begin{array}{l}\text { Absorption edge } \\
(\mathrm{nm})\end{array}$ \\
\hline $450 / 4$ & anatase & 10 & 3.24 & 383 & anatase & 9 & 3.24 & 383 \\
\hline $550 / 4$ & anatase & 10 & 3.11 & 399 & anatase & 12 & 3.12 & 397 \\
\hline $650 / 4$ & anatase & 31 & 3.17 & 391 & anatase & 20 & 3.22 & 385 \\
\hline $450 / 8$ & anatase & 9 & 3.16 & 392 & anatase & 11 & 3.14 & 395 \\
\hline $450 / 12$ & anatase & 11 & 3.11 & 399 & anatase & 11 & 3.20 & 388 \\
\hline
\end{tabular}




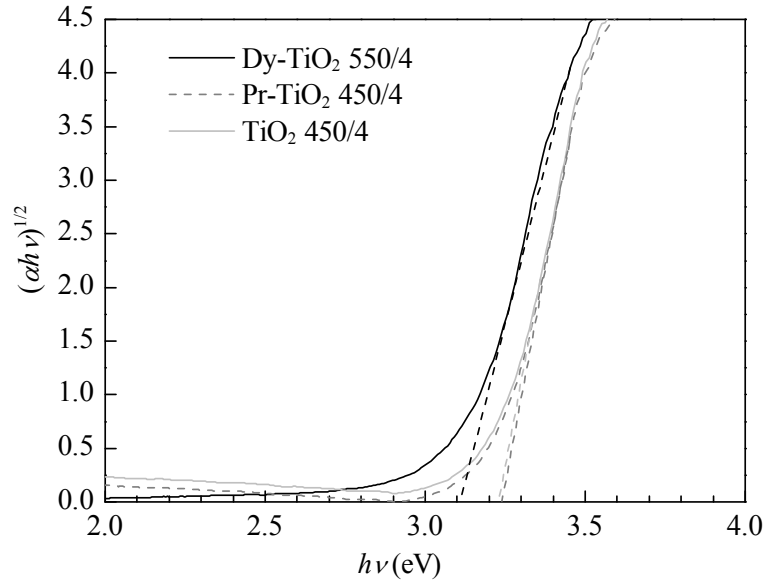

Fig. 4. Kubelka-Munk plots used to calculate band gap energy.

$=C\left(h v-E_{\mathrm{g}}\right)[22]$. The band gap energy for each sample was evaluated from relation $(\alpha h v)^{1 / 2}=f(h v)$ by extrapolation of the linear part of the curve in Fig. 4 . The calculated $E_{\mathrm{g}}$ are summarized in Table 1 . Values around $3.2 \mathrm{eV}$ correspond to the anatase crystalline phase. These results confirm the results of the XRD and Raman analyses.

\subsection{Particle size and specific surface area}

The changes in the morphology of the prepared powders were examined by scanning electron microscopy, which revealed a difference between the Dy- and Pr-doped titania samples (Fig. 5). The particle size and consequently the size of the aggregates were larger in the samples doped with dysprosium. Although the particle size did not seem to be much affected by the synthesis conditions, the conditions significantly influenced the aggregate size (Table 2 and Fig. 5). The smallest aggregates were formed at a solid state reaction temperature of $550{ }^{\circ} \mathrm{C}$ and time of $8 \mathrm{~h}$ for both lanthanides. The results of the specific surface area measurements from BET analysis are summarized in Table 2. It can be seen that the specific surface area decreased with increasing aggregate size.

\subsection{Photocatalytic activity}

Before the photocatalytic experiments, an adsorption was carried out to determine the time needed to achieve adsorption/desorption equilibrium. The results are shown in Fig. 6 and indicate that the required time was $5 \mathrm{~min}$. Within this time, the concentration of metazachlor in the solution decreased from 10 to $8.2 \mathrm{mg} / \mathrm{L}$ and then remained nearly constant.

The photocatalytic experiments were performed in a flow reactor. Each experiment lasted $60 \mathrm{~min}$, which corresponded to 10 min of contact time (where the photocatalyst was exposed to the LED source). The decrease in metazachlor concentration determined by HPLC was used to calculate the initial rate of metazachlor decomposition. Metazachlor belongs to the chlo-
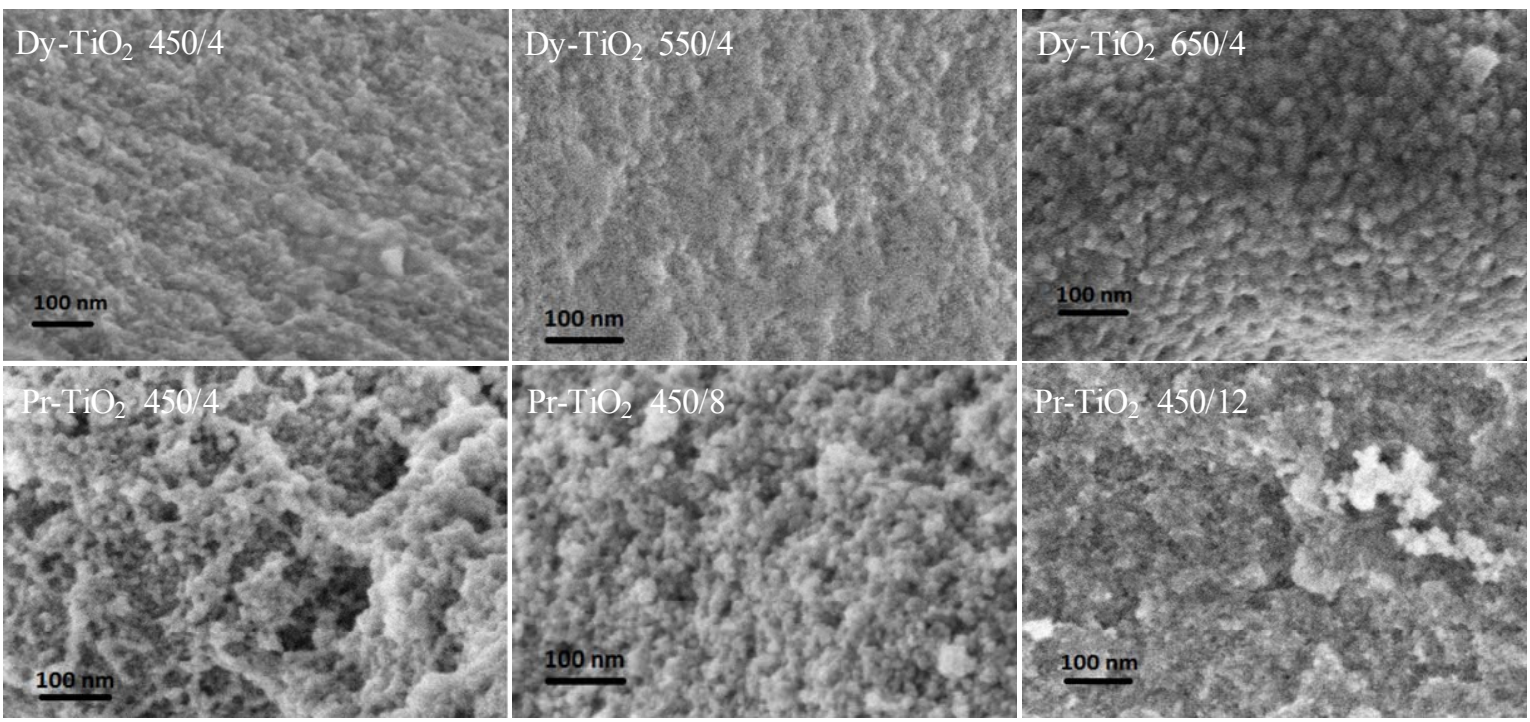

Fig. 5. Scanning electron microscopy images of $\mathrm{TiO}_{2}$ samples doped with dysprosium and praseodymium.

Table 2

Particle size results from SEM and BET analysis.

\begin{tabular}{|c|c|c|c|c|c|c|}
\hline \multirow{2}{*}{$\begin{array}{l}\text { Treatment conditions } \\
\left({ }^{\circ} \mathrm{C} / \mathrm{h}\right)\end{array}$} & \multicolumn{3}{|c|}{ Dy-TiO ${ }_{2}$} & \multicolumn{3}{|c|}{$\mathrm{Pr}-\mathrm{TiO}_{2}$} \\
\hline & $\begin{array}{c}\text { Particles size } \\
(\mathrm{nm})\end{array}$ & $\begin{array}{l}\text { Aggregates size } \\
(\mathrm{nm})\end{array}$ & $\begin{array}{c}\text { Specific surface area } \\
\left(\mathrm{m}^{2} / \mathrm{g}\right)\end{array}$ & $\begin{array}{c}\text { Particles size } \\
(\mathrm{nm})\end{array}$ & $\begin{array}{l}\text { Aggregates size } \\
(\mathrm{nm})\end{array}$ & $\begin{array}{c}\text { Specific surface area } \\
\left(\mathrm{m}^{2} / \mathrm{g}\right)\end{array}$ \\
\hline $450 / 4$ & 25 & 750 & 60.4 & 20 & 500 & 77.5 \\
\hline $550 / 4$ & 25 & 500 & 73.6 & 23 & 150 & 89.9 \\
\hline $650 / 4$ & 30 & 700 & 66.9 & 25 & 400 & 82.8 \\
\hline $450 / 8$ & 20 & 300 & 80.6 & 20 & $<100$ & 106.3 \\
\hline $450 / 12$ & 25 & 500 & 72.4 & 22 & 400 & 83.1 \\
\hline
\end{tabular}




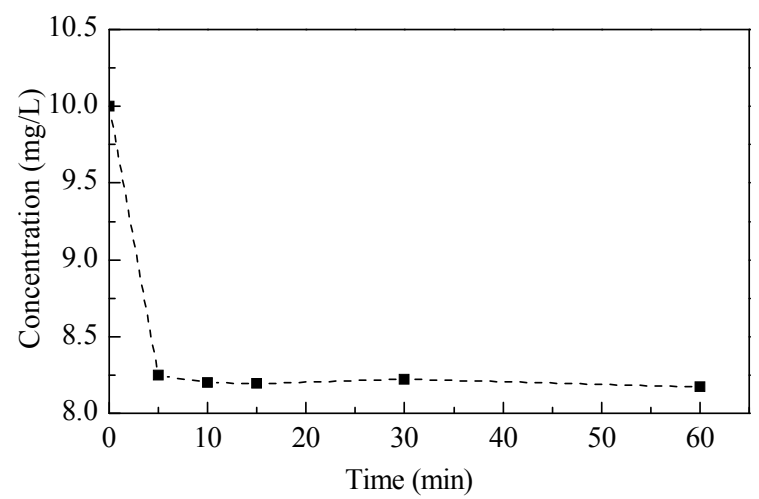

Fig. 6. Decrease in concentration of metazachlor during the adsorption/desorption test.

roacetamide herbicides, which undergo dechlorination in the first step of photodegradation. This process is subsequently followed by mono- or multi-hydroxylation and cyclization.

The contribution of direct photolysis was subtracted from the observed rate of decomposition. The influence of the solid state reaction temperature and time was examined, and the best performing materials for the decomposition were found to be those prepared at $550{ }^{\circ} \mathrm{C}$ and $8 \mathrm{~h}$, both the dysprosium and the praseodymium doped samples. The results are shown in Fig. 7. We conclude that the increased rates were a result of the creation of smaller aggregates (as shown by the SEM results), because smaller particles (or more precisely, smaller aggregates) should have higher specific surface area and hence, more specific sites where reactions can occur. The Pr-doped $\mathrm{TiO}_{2}$ samples exhibited higher activity than Dy-doped samples prepared under the same synthesis conditions. Moreover, we compared the initial degradation rate of the doped $\mathrm{TiO}_{2}(450 / 4$ and 550/4) with that of undoped $\mathrm{TiO}_{2}$ prepared under the same conditions and commercial titania Degussa P25, and found that doping increased the photocatalytic activity (Table $3)$. This can be explained by the fact that the rate of back recombination $\left(\mathrm{e}^{-} / \mathrm{h}^{+}\right)$in pure $\mathrm{TiO}_{2}$ is quite fast, and consequently its activity is limited. Generally, the transitions of $4 f$ electrons of rare earth elements are responsible for the optical absorption of a doped catalyst and support the separation of photo-generated $\mathrm{e}^{-} / \mathrm{h}^{+}$pairs. Lanthanide ions behave as a scavenger of excited electrons from the titania conduction band [23].

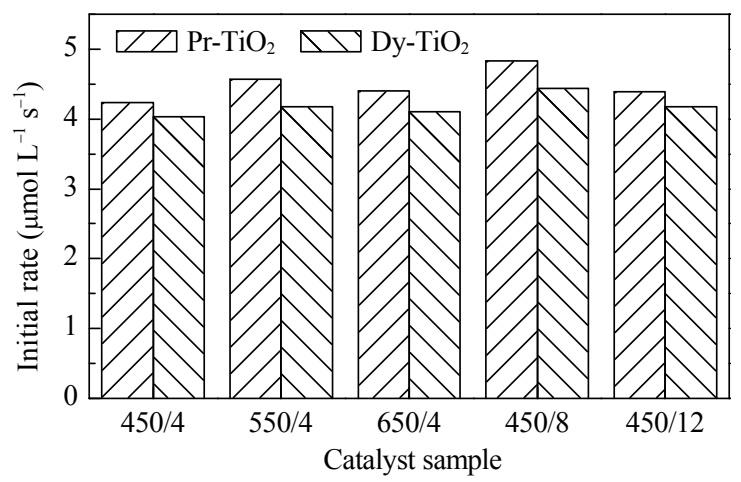

Fig. 7. Initial rates of metazachlor degradation over different catalyst samples.
Table 3

Comparison of initial degradation rate $\left(\mu \mathrm{mol} \mathrm{L} \mathrm{L}^{-1} \mathrm{~s}^{-1}\right)$ for doped and undoped $\mathrm{TiO}_{2}$ samples and commercial titania P25.

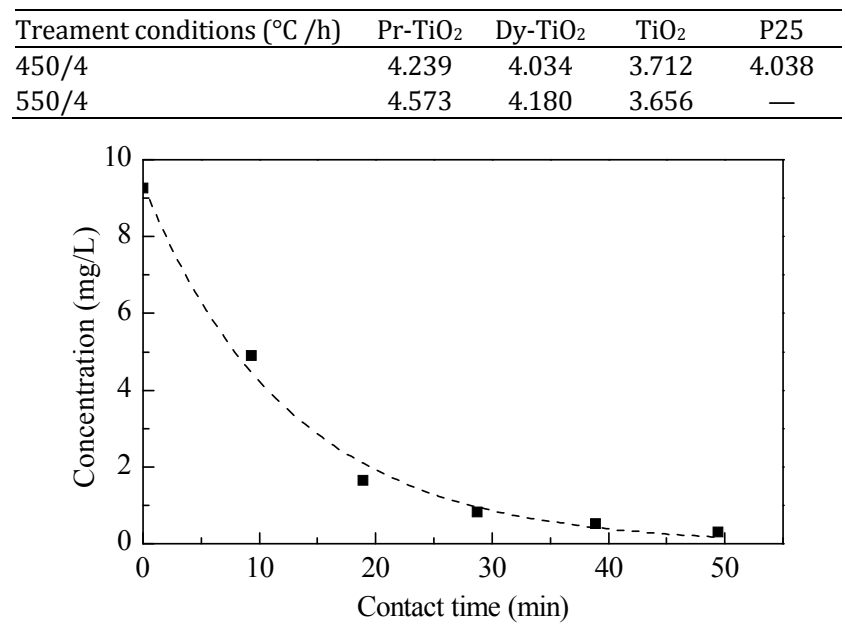

Fig. 8. Decrease in metazachlor concentration with time using $\mathrm{Dy}_{-} \mathrm{TiO}_{2}$ $450 / 4$.

Dy-doped $\mathrm{TiO}_{2} 450 / 4$, the least photocatalytically active sample, was used in further experiments to investigate the time required for total decomposition of metazachlor. We found that $5 \mathrm{~h}$, which corresponded to 50 min of contact time, was sufficient to lower the metazachlor concentration nearly to zero (as shown in Fig. 8). Complete photocatalytic decomposition of mezatachlor in water after $1 \mathrm{~h}$ of irradiation total is a comparable time to that reported in the literature [24], which indicates that the photocatalysts prepared in this work were efficient and suitable for this purpose. Furthermore, our results indicate that increasing the amount of lanthanides in the sample could lead to lower band gap energy owing to a shift of the absorption edge towards the visible range.

\section{Conclusions}

Dysprosium and praseodymium doped titania powders were prepared by sol-gel synthesis and subsequent solid state reaction treatment. All prepared samples were found to be suitable for photocatalytic decomposition of metazachlor in water; the best photocatalyst for this purpose was $\mathrm{Pr}_{-} \mathrm{TiO}_{2}$ treated at $450{ }^{\circ} \mathrm{C}$ for $8 \mathrm{~h}$. All the prepared photocatalysts were more active than or comparable in activity with commercial titanium dioxide P25. The aggregate size and consequently, the specific surface area, of the photocatalysts very significantly affected their final activity. Moreover, the lower activity of pure $\mathrm{TiO}_{2}$ prepared under the same conditions confirmed that the Dy and Pr dopants enhanced photocatalytic activity.

\section{Acknowledgments}

The authors thank the Ministry of Education, Youth and Sport of the Czech Republic for support through project CZ.1.07/2.3.00/30.0005, as well as the Central European Institute of Technology (CEITEC). The authors also appreciate the work of Zdenek Spotz, who performed the XRD analysis, Zorka 


\title{
Graphical Abstract
}

Chin. J. Catal., 2015, 36: 1679-1685 doi: 10.1016/S1872-2067(15)60943-3

Influence of synthesis conditions on physical properties of lanthanide-doped titania for photocatalytic decomposition of metazachlor

Marcela Kralova*, Irina Levchuk, Vit Kasparek, Mika Sillanpaa, Jaroslav Cihlar

Brno University of Technology, Czech Republic; Lappeenranta University of Technology, Finland

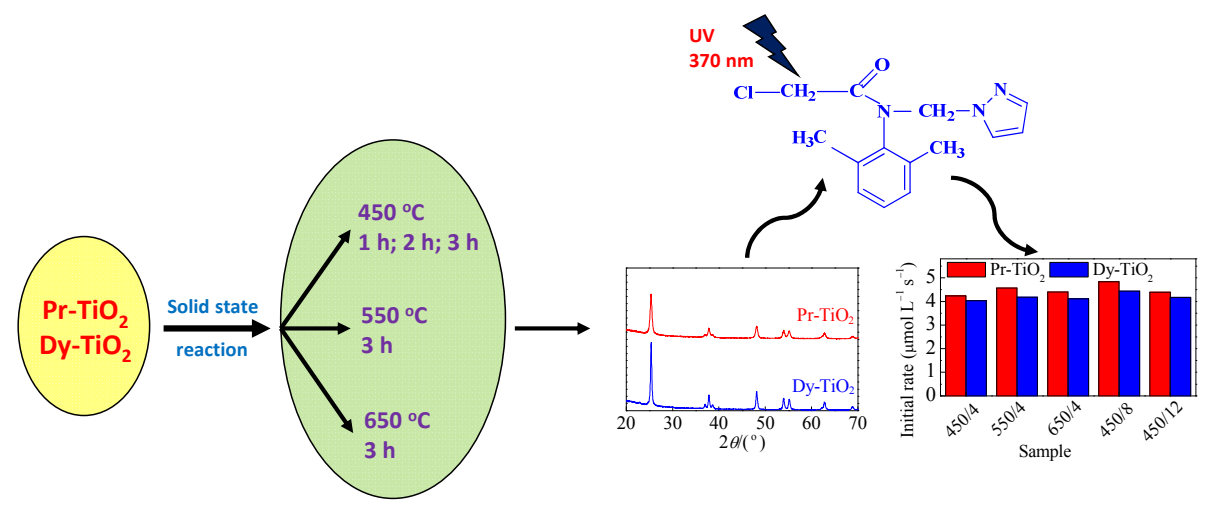

Praseodymium-doped titania shows higher photocatalytic activity than P25. The synthesis conditions significantly affected the physical properties of the photocatalysts and consequently their activity, which was mainly dependent on specific surface area.

Cihlarova, who performed the BET analysis, Jan Cupera, who performed the SEM imaging, and Dusan Hemzal, who performed Raman analysis.

\section{References}

[1] Musil B. http://www.apic-ak.cz/data_ak/11/v/UcinneLatky Spotreba2010. pdf

[2] Sanches S, Penetra A, Rodrigues A, Cardoso V V, Ferreira E, Benoliel M J, Barreto Crespo M T, Crespo J G, Pereira V J. Separat Purificat Technol, 2013, 115: 73

[3] FAO specifications and evaluations for plant protection products: Matazachlor. Food and Agriculture Organization of the United Nations, 1999. http://www.fao.org/fileadmin/templates/agphome/ documents/Pests_Pesticides/Specs/metazach.pdf

[4] Schug T T, Janesick A, Blumberg B, Heindel J J. J Ster Biochem Mol Biol, 2011, 127: 204

[5] Deblonde T, Hertemann P. Pub Health, 2013, 127: 312

[6] Michael I, Rizzo L, McArdell C S, Manaia C M, Merlin C, Schwartz T, Dagot C, Fatta-Kassinos D. Water Res, 2013, 47: 957

[7] Verlicchi P, Al Aukidy M, Galletti A, Petrovic M, Barcelo D. Sci Total Environ, 2012, 430: 109

[8] Cruz-Morato C, Lucas D, Llorca M, Rodriguez-Mozaz S, Gorga M, Petrovic M, Barcelo D, Vincent T, Sarra M, Marco-Urrea E. Sci Total Environ, 2014, 493: 365
[9] Silva C P, Otero M, Esteves V. Environ Pollut, 2012, 165: 38

[10] Hinkova A, Henke S, Bubnik Z, Pour V, Salova A, Slukova M, Sarka E. Innov Food Sci Emerg Technol, 2015, 27: 129

[11] Malato S, Fernandez-Ibanez P, Maldonado M I, Blanco J, Gernjak W. Catal Today, 2009, 147: 1

[12] Yu J G, Xiang Q J, Zhou M H. Appl Catal B, 2009, 90: 595

[13] Chiou C H, Juang R S.J Hazard Mater, 2007, 149: 1

[14] Reszczynska J, Esteban D A, Gazda M, Zaleska A. Physicochem Probl Miner Process, 2014, 50: 515

[15] Liang C H, Liu C S, Li F B, Wu F. Chem Eng J, 2009, 147: 219

[16] Huang F P, Wang S, Zhang S, Fan Y G, Li C X, Wang C, Liu C. Bull Korean Chem Soc, 2014, 35: 2512

[17] Shi L, Cao L X, Gao R J, Zhao Y L, Zhang H B, Xia C H. J Alloys Compd, 2014, 617: 756

[18] Shi J W, Zheng J T, Wu P.J Hazard Mater, 2009, 161: 416

[19] Han F, Kambala V S R, Srinivasan M, Rajarathnam D, Naidu R. Appl Catal A, 2009, 359: 25

[20] Shi H X, Zhang T Y, Wang H L. J Rare Earth, 2011, 29: 746

[21] Yang L, Kruse B. J Opt Soc Am A, 2004, 21: 1933

[22] Nishanthi S T, Raja D H, Subramanian E, Padiyan D P. Electrochim Acta, 2013, 89: 239

[23] Stengl V, Bakardjieva S, Mufara N. Mater Chem Phys, 2009, 114: 217

[24] Vranjes M, Saponjic Z V, Zivkovic L S, Despotovic V N, Sojic D V, Abramovic B F, Comor M I. Appl Catal B, 2014, 160-161: 589

\section{制备条件对稀土掺杂 $\mathrm{TiO}_{2}$ 物理性质和光催化降解吡唑草胺性能的影响}

\author{
Marcela Kralova ${ }^{a}{ }^{,}$, Irina Levchuk ${ }^{\text {b }}$, Vit Kasparek ${ }^{\text {a }}$, Mika Sillanpaa ${ }^{\text {, }}$, Jaroslav Cihlar ${ }^{\text {a }}$ \\ a布尔诺理工大学中欧科技学院, 布尔诺, 捷克共和国 \\ $\mathrm{b}^{\mathrm{b}}$ 拉普兰塔理工大学绿色化学实验室, 米凯利, 芬兰
}


了 $\mathrm{TiO}_{2}$ 样品. 运用X射线衍射分析了该样品的晶相, 发现只存在锐钛矿相, 并得到Raman光谱的证实. 同时采用扫描电镜观察了样 品的结构和粒径; 以BET法计算了其比表面积; 运用紫外-可见光漫反射光谱测得了样品的带隙能量. 通过测量紫外光照射下常 用除草剂吡唑草胺的降解速率评价了样品的光催化活性, 反应过程中吡唑草胺的浓度用高效液相色谱分析. 结果表明, 稀土掺杂 使得 $\mathrm{TiO}_{2}$ 吸收边红移, 并提高了其光催化活性; 制备时最优的固态反应条件为 $550{ }^{\circ} \mathrm{C} 反$ 应 $8 \mathrm{~h}$.

关键词: 稀土掺杂二氧化钛; 镝; 镨; 合成条件; 光催化降解; 吡唑草胺

收稿日期: 2015-02-28. 接受日期: 2015-06-17. 出版日期: 2015-10-20.

*通讯联系人. 电话: +420 541143 340; 传真: +420 541211 309; 电子信箱: marcela.kralova@ceitec.vutbr.cz

本文的英文电子版由Elsevier出版社在ScienceDirect上出版(http://www.sciencedirect.com/science/journal/18722067). 